\title{
Liter per Picogram per Day
}

National Cancer Institute

\section{Source}

National Cancer Institute. Liter per Picogram per Day. NCI Thesaurus. Code C85693.

Liters per picogram per day. 